\title{
PENYULUHAN KEAMANAN PANGAN PADA KEDAI KOPI DI SURABAYA DI MASA PANDEMI COVID - 19
}

\author{
Latifahtur Rahmah $^{1 *}$, Angeline Listiyani Utomo ${ }^{2}$, Go Fernando Wibisono ${ }^{3}$ \\ 1,2,3 Akademi Kuliner dan Patiseri Ottimmo Internasional, \\ Jl. Telaga Golf TC 4 42-3 Citraland, Surabaya 60217 \\ *Penulis korespondensi; Email: latifahturrahmah@ottimmo.ac.id
}

\begin{abstract}
Abstrak: Insan industri makanan, termasuk kedai kopi, tidak memiliki kesempatan untuk bekerja dari rumah dan diharuskan untuk tetap bekerja di tempat kerja seperti biasa. Dengan mengadakan sosialisasi tentang keamanan pangan, menjaga semua pekerja dalam produksi pangan dan rantai pasokan tetap sehat dan aman sangat penting untuk bertahan dari pandemi saat ini. Menjaga pergerakan makanan di sepanjang rantai makanan merupakan fungsi penting yang perlu disumbangkan oleh semua pemangku kepentingan di sepanjang rantai makanan. Pengabdian kepada masyarakat ini bertujuan untuk menambah pengetahuan atau informasi tentang keamanan pangan bagi penjamah makanan atau minuman sehingga warung kopi lebih siap menghadapi kondisi COVID-19. Untuk memudahkan komunikasi, penyuluhan menggunakan poster dan membagi pembahasan keamanan pangan menjadi 4, yaitu: 1) keamanan pangan produsen; 2) distributor keamanan pangan; 3) keamanan pangan konsumen 4) Keamanan pangan produksi pangan. Setelah diberikan penyuluhan, dilakukan evaluasi dengan mengukur pengetahuan karyawan menggunakan perbandingan kuesioner pre-test dan post-test yang diberikan melalui google form. Hasil evaluasi menyatakan bahwa seluruh karyawan di delapan kedai kopi tersebut mengalami peningkatan pengetahuan tentang keamanan pangan. Sebagian besar karyawan merasa kegiatan pengabdian masyarakat dengan penyuluhan bermanfaat untuk menjaga keamanan di warung kopi sehingga dapat membuat karyawan dan pelanggan merasa aman dan nyaman.
\end{abstract}

Kata kunci: Kedai Kopi, Covid-19, Keamanan Pangan.

\begin{abstract}
Food industry personnel, including coffee shops, do not have the opportunity to work from home and are required to continue working at work as usual. By holding outreach on food safety keeping all workers in food production and supply chains healthy and safe is critical to surviving the current pandemic. Maintaining the movement of food along the food chain is an important function that needs to be contributed by all stakeholders along the food chain. The purpose of this community service is to increase knowledge or information about food safety for food or beverage handlers so that coffee shops are better prepared to deal with COVID-19 conditions. To facilitate the communication of counseling using poster, and divided the discussion of food safety into 4, namely: 1) food safety of producers; 2) food safety distributors; 3) food safety of consumers 4) Food safety of food production. After being given counseling, an evaluation was carried out by measuring employee knowledge using a comparison of pre-test and post-test questionnaires given through the google form. The results of the evaluation stated that all employees in the eight coffee shops had increased knowledge about food safety. Most of the employees felt that community service activities with counseling were useful for maintaining security in coffee shops so that they could make employees and customers feel safe and comfortable.
\end{abstract}

Keywords: Coffee shop, Covid-19, Food Safety.

\section{PENDAHULUAN}

Menurut WHO virus corona yaitu sekelompok virus yang dapat menyebabkan penyakit pada hewan ataupun manusia (WHO. 2020). Beberapa jenis virus corona diketahui menyebabkan infeksi saluran pernapasan pada manusia mulai dari batuk pilek hingga yang lebih serius seperti Middle East Respiratory Syndrome (MERS) dan Severe Acute Respiratory Syndrome (SARS). Virus Corona yang baru ditemukan, menyebabkan penyakit COVID-19. Infocovid Jatim (2020) melalui situs 
resminya, berdasarkan pemutakhiran data tertanggal 18 Agustus 2020 menunjukkan terdapat 40.460 pasien yang dipastikan aktif untuk tingkat nasional, sedangkan untuk tingkat provinsi ada 4.864 pasien yang dikonfirmasi aktif (Infocovid Jatim, 2020).

WHO dan UNICEF menjabarkan bahwa terdapat dua jalur penularan utama dari virus COVID-19: pernapasan dan kontak. Percikan pernapasan berasal dari batuk atau bersin orang yang terinfeksi. Setiap orang yang memiliki kontak erat dengan seseorang yang memiliki gejala permasalahan pernapasan (seperti bersin dan batuk) berisiko tepapar percikan yang terinfeksi. Satu percikan tadi mungkin jatuh pada permukaan dimana virus dapat bertahan, untuk itu lingkungan sekitar individu yang terinfeksi dapat menjadi sumber penularan (disebut dengan penularan melalui kontak). Belum dapat dipastikan berapa lama virus COVID-19 dapat bertahan pada permukaan benda, tetapi besar kemungkinan memiliki karakter yang sama dengan tipe virus corona lainnya. Baru-baru ini terdapat sebuah tinjauan tentang ketahanan virus corona pada permukaan benda yang menunjukan beragam temuan berkisar antara dua jam sampai sembilan hari. Waktu bertahan sangat bergantung oleh banyak faktor, termasuk bahan permukaan, suhu, kelembapan, dan jenis virus tertentu. Tinjauan yang sama juga menyebutkan bahwa cara efektif membunuh virus dalam satu menit dapat dilakukan dengan disinfektan biasa, seperti alkohol $70 \%$ atau dengan sodium hypochlorite (WHO \& UNICEF, 2020).

Teknologi Pangan mempunyai peranan untuk menghasilkan suatu produk pangan yang aman dan bermutu. Sehingga secara sadar dan bertanggung jawab, aspek keamanan pangan harus masuk dalam kegiatan perancangan, yaitu sejak perancangan lokasi, bangunan, mesin dan peralatan, produk, kemasan, penyimpanan dan penggudangan, distribusi, sampai pada penjajaan tahap ritel, serta penanganan rumah tangga dan konsumsi (Hariyadi P, 2018).

Mengonsumsi pangan yang tidak aman dapat membahayakan kesehatan dan jiwa konsumen. Namun, hingga saat ini peredaran pangan yang tidak aman masih menjadi permasalahan bagi Indonesia. Meskipun ketentuan mengenai keamanan pangan sudah diatur dalam Undang-Undang (UU) tentang Pangan dan UU tentang Kesehatan. Tulisan ini menggunakan studi pustaka. Analisis menggunakan teori dan konsep pada literatur sebagai objek utama untuk menjawab pertanyaan terkait bagaimana kondisi penyelenggaraan keamanan pangan di Indonesia dan berbagai faktor yang perlu diperhatikan dalam penyelenggaraan keamanan pangan agar hak masyarakat sebagai konsumen dapat terlindungi (Lestari TRP, 2018).
Food Safety Authority of Irleland (2001) Pelatihan keamanan pangan merupakan komponen penting dari setiap bisnis makanan dalam memastikan budaya keamanan pangan. Merupakan persyaratan hukum bahwa staf yang terlibat dalam lingkungan makanan mendapatkan pelatihan yang memadai dan/atau diawasi sesuai dengan aktivitas kerja mereka (Food Safety Authority of Irleland. 2001). Panduan penyuluhan food safety yang baik terdiri dari identifikasi bahaya yang dapat menyebabkan penyakit bawaan makanan, pahami pentingnya mencuci tangan yang benar dan kesehatan Anda, ketahui suhu makanan yang aman untuk menghindari zona bahaya. mengikuti dan pahami aturan keamanan pangan umum, gunakan pengetahuan ini untuk penanganan makanan yang lebih aman di tempat kerja dan di rumah (Morris, 2011).

Pada era new normal tuntutan untuk memulai kembali berbagai aktivitas sosial dan ekonomi dapat dilakukan, namun dengan standar kesehatan, fasilitas kerja dan infrastruktur publik yang memungkinkan manusia untuk hidup berdampingan dengan Covid-19 yang belum pergi. Pada era new normal, banyak usaha jasa boga yang membuka kembali usahanya. Usaha jasa boga dapat menjadi tempat penularan Covid-19 karena memiliki rantai yang cukup panjang dari mulai produsen, distributor, konsumen hingga pengantaran makanan sehingga dibutuhkan penyuluhan keamanan pangan untuk memutus penyebaran berbagai macam virus dan mengambil kembali kepercayaan konsumen (Muhyiddin M, Nugroho H. 2020).

Personel industri makanan tidak memiliki kesempatan untuk bekerja dari rumah dan diharuskan untuk terus bekerja di tempat kerja yang biasa. Agar semua pekerja di produksi makanan dan rantai pasokan sehat dan aman sangat penting untuk bertahan dari pandemi saat ini. Mempertahankan pergerakan makanan di sepanjang rantai makanan merupakan langkah penting yang perlu dipikirkan oleh semua pemangku kepentingan terkait. Hal ini juga diperlukan untuk menjaga kepercayaan konsumen terhadap keamanan dan ketersediaan pangan.

Banyak sekali bermunculan kedai kopi yang menjual berbagai kreasi minuman kopi. Indonesia Data melaporkan pada tahun 2020 terdapat 350 kedai kopi di Surabaya. Tren gaya hidup atau lifestyle mengkonsumsi kopi di era modern seperti saat ini mulai berkembang dan merambah masyarakat khususnya di wilayah perkotaan (As'ad MH, Aji JMM. 2020). Di Tengah kondisi covid ini memulai kembali berbagai aktivitas sosial dan ekonomi dapat dilakukan, namun diwajibkan menggunakan standar Kesehatan kerja. Pemberian pengetahuan atau informasi mengenai keamanan pangan perlu dilakukan pada penjamah makanan 
atau minuman agar kedai kopi lebih siap menghadapi covid 19 melatar belakangi penyuluh melakukan survey pada kedai kopi disurabaya dan hasil survei tersebut rata-rata kedai kopi di Surabaya belum pernah mendapatkan penyuluhan keamanan pangan yang disesuaikan dengan kondisi new normal. Berdasarkan uraian tersebut maka didapatlah tujuan dilakukan pengabdian manyarakat ini adalah meningkatkan pengetahuan atau informasi mengenai keamanan pangan pada penjamah makanan atau minuman agar kedai kopi lebih siap menghadapi kondisi covid 19.

\section{METODE PELAKSANAAN}

Kegiatan pengabdian masyarakat ini dilakukan dengan metode penyuluhan. Sasaran penyuluhan adalah kedai kopi - kedai kopi yang ada di kota Surabaya propinsi Jawa Timur Indonesia. Subjek kegiatan atau perserta pelatihan berjumlah delapan orang perwakilan pegawai dari delapan kedai kopi di Surabaya. Selanjutnya perwakilan pegawai yang diberi penyuluhan akan memberikan penyuluhan kepada rekan ditempat kerjanya menggunakan poster yang diberikan. Program pengabdian masyarakat meliputi: keamanan pangan produsen, distributor, konsumen hingga makanan.

Kegiatan penyuluhan dalam bentuk pemberian materi melalui poster dengan waktu yang berbeda antar kedai kopi. Penyuluhan dilakukan diwaktu yang berbeda karena adanya peraturan pemerintah untuk melakukan pembatasan sosial. Dalam bentuk mengevaluasi kegiatan ini sebelum dan sesudah penyuluhan pegawai akan diberi soal pre test dan post test.

\section{HASIL dan PEMBAHASAN}

Pemberlakuan protokol kesehatan dalam new normal ini dapat diartikan sebagai health transition dari pandemi COVID-19, dimana terjadi perubahan sosial dalam hal persepsi masyarakat mengenai penentu kesehatan. Terdapat beberapa perubahan dalam memberi pelatihan mulai dari social distancing dan menggunakan alat pelindung diri secara ketat. Sebelum dilakukan penyuluhan peserta diberi gambaran umum mengenai pengertian keamanan pangan dan juga macam-macam kerusakan pada makanan.

Menjaga keamanan pangan menjadi tanpa syarat dalam hal perdagangan makanan dan permintaan pelanggan. Pangan yang dipasarkan harus berkualitas baik dan aman dikonsumsi, serta tidak menjadi sumber penyakit dan infeksi. Untuk alasan ini, pengamanan keamanan dan kualitas pangan adalah masalah yang penting secara internasional dan menjadi tanggung jawab pro- dusen dan pemerintah pangan. Selama proses distribusi produk pangan melalui semua tahapan rantai pasok, semua proses yang menggambarkan bagaimana makanan berpindah dari sebuah peternakan ke meja konsumen disebut "from the field to the table", adalah untuk mencapai pengawasan penuh atas keamanan pangan di dunia modern, karena perjalanan menuju produksi pangan ke konsumen sangat memakan waktu dan ruang. Dalam perjalanan ini, banyak sekali bahaya pencemaran makanan, baik itu di bagian produsen, distributor, konsumen dan makanan. Untuk memungkinkan kualitas pangan dan keamanan sanitasi produk makanan, perusahaan harus mengikuti peraturan perundang-undangan, standar, dan norma di setiap tahap rantai pasokan (Bendeković J, Naletina D, Nola I. 2015).

Untuk mempermudah komunikasi penyuluhan, peneliti membagi pembahasan keamanan pangan menjadi 4 yaitu: 1) keamanan pangan produsen; 2) keamanan pangan distributor; 3) keamanan pangan konsumen 4) Keamanan pangan produksi makanan. Kemananan harus dikomunikasikan dalam bentuk yang mudah dimengerti. WHO akan mendukung pengembangan metode untuk mendorong dialog penyuluhan di antara, dan partisipasi, pemangku kepentingan, termasuk konsumen, dalam proses komunikasi. Metode untuk menilai efek komunikasi risiko harus dievaluasi.

\section{Keamanan Pangan Produsen}

Keamanan pangan produsen meliputi petani hingga penjual bahan makanan. Produsen adalah pihak yang paling bertanggung jawab atas keamanan pangan dan kualitas pangan bagi produsen yang memproduksi pangan. Faktor utama yang menjamin ketahanan pangan perlu diperhatikan oleh produsen, yaitu pemilihan bahan baku yang akan digunakan dalam proses produksi. Bahan baku yang akan digunakan harus sesuai dengan spesifikasi bahan perusahaan karena akan menentukan keamanan dan kualitas produk akhir (Sjafrina N, Yani A. 2013).

\section{Keamanan Pangan Distributor}

Tindakan pencegahan yang tepat diperlukan untuk meminimalkan potensi penularan virus selama transaksi yaitu dengan pembayaran online telah memperkenalkan pengiriman bebas kontak ke rumah. Pemilihan transportasi juga menjadi fokus utama dalam keamanan pangan (Olaimat, Shahbaz, Fatima, Munir, Holley. 2020). Setelah pengemasan produk, rantai pasokan terdiri dari beberapa tahap lagi di mana pilihan harus dibuat untuk menggunakan transportasi. Karakteristik penting dari banyak sistem distribusi makanan 
adalah pengatur suhu. Untuk berbagai macam produk, pengatur suhu sangat penting untuk mengontrol kualitas dan keamanan pangan. Namun hal itu menyebabkan penggunan energi tambahan seperti kotak pemanasan atau kotak pendingin. Dengan demikian, distribusi yang dikendalikan suhu dapat menjaga kualitas dan keamanan (Akkerman R, Farahani P, Grunow M. 2010).

\section{Keamanan Pangan Konsumen}

Persepsi konsumen tentang keamanan makanan sangat penting bagi manajer dan pemilik kedai kopi karena persepsi ini dapat mengakibatkan hilangnya pelanggan jika konsumen memilih untuk makan di kedai kopi yang "lebih aman". Membuat lingkungan yang nyaman dapat dengan menyajikan makanan dalam keadaan bersih, menyediakan tempat cuci tangan, memberi tisue di atas meja hingga penampilan pegawai (Knight AJ, Worosz MR, Todd ECD. 2007). Kerusakan keamanan pangan terjadi ketika bakteri, virus, atau parasit penyebab penyakit tertentu mencemari makanan, mereka dapat menyebabkan penyakit terkait makanan. Kata lain untuk bakteri, virus, atau parasit tersebut adalah "patogen". Karena penyakit yang berhubungan dengan makanan bisa serius, atau bahkan fatal, itu penting. Keamanan pangan adalah jaminan bahwa pangan tidak akan membahayakan konsumen bila disiapkan dan dimakan sesuai dengan tujuan penggunaannya. Proses penyebaran penyakit bawaan makanan dimulai dengan ciri-ciri penyakit, mencemari makanan, yang selanjutnya mengancam kesehatan individu dan masyarakat melalui makanan tersebut. Makanan sehat atau yang bisa disebut makanan aman adalah makanan yang tidak kehilangan nilai gizinya, yaitu bersih, baik secara fisik, kimiawi, maupun mikrobiologis dan tidak basi (Uçar A, Yilmaz MV, Çakiroglu FP. 2016).

\section{Keamanan Produksi Makanan}

Bisnis makanan harus mematuhi persyaratan pengaturan suhu pada makanan, mereka harus dapat menunjukkan bahwa mereka memiliki sistem pemasakan makanan hingga penyimpanan makanan yang aman untuk memastikan bahwa makanan tetap aman untuk dimakan. Beberapa makanan yang tidak berpotensi berbahaya dapat menjadi berpotensi berbahaya jika anda tidak memperhatikan suhu zona bahaya makanan (. Food Safety Standards, 2008). Zona berbahaya adalah kisaran suhu antara $40^{\circ} \mathrm{F}$ dan $140^{\circ} \mathrm{F}$, biasanya terletak di suhu ruangan bukan di suhu pendingin ataupun suhu pemasakan yang mendorong pertumbuhan bakteri dalam makanan yang mudah rusak. Ketika makanan yang mudah busuk berada dalam kisaran suhu tersebut, pertumbuhan bakteri dapat terjadi. Pertumbuhan bakteri dapat menyebabkan penyakit bawaan makanan (Messing, L. 2015).

Penyuluhan terhadap kedai kopi di Surabaya diadakan di delapan kedai kopi kedai kopi Soe, Kudos, kedai kopi Bugs, kedai kopi Gringo, kedai kopi Kenangan, kedai kopi Titik Terang Kopi, kedai kopi Higayon Ca N Co, kedai kopi Sini Aja. Di karenakan pandemi covid 19, penyuluhan hanya diberikan kepada salah satu pegawai di kedai kopi tersebut sehingga total pegawai yang mengikuti penyuluhan sebanyak 8 orang. Dari perwakilan pegawai yang mengikuti penyuluhan diharapkan dapat memyebarkan ilmu yang didapat ke rekan kerja yang lain. Jadwal penyuluhan keamanan pangan di Surabaya ditunjukan pada Tabel 1.

Tabel 1. Jadwal Penyuluhan Keamanan Pangan di Surabaya

\begin{tabular}{clll}
\hline No & Nama Kedai kopi & Hari & Tanggal \\
\hline 1 & Soe Citraland & Jumat & 23 Oktober 2020 \\
2 & Kudos & Sabtu & 24 Oktober 2020 \\
3 & Bugs & Sabtu & 24 Oktober 2020 \\
4 & Gringo & Senin & 26 Oktober 2020 \\
5 & Kopi Kenangan & Selasa & 27 Oktober 2020 \\
6 & Titik Terang Kopi & Rabu & 28 Oktober 2020 \\
7 & Higayon Ca N Co & Minggu & 1 November 2020 \\
8 & Sini Aja & Minggu & 1 November 2020 \\
\hline
\end{tabular}

Poster keamanan pangan sebagai materi kegiatan dapat dilihat pada gambar 1 .

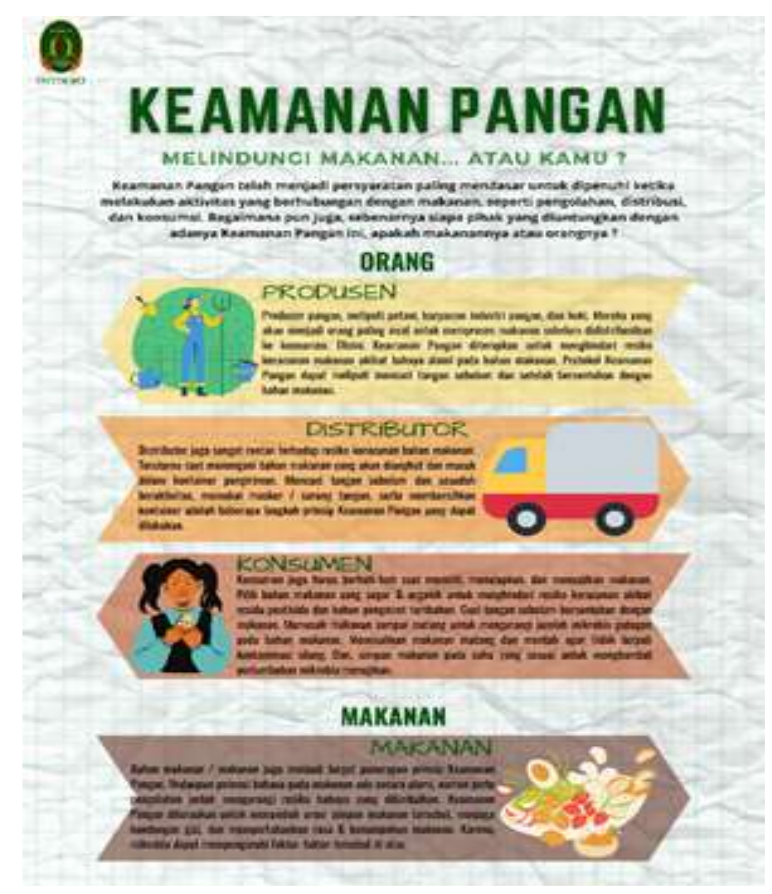

Gambar 1. Poster Keamanan Pangan 
Poster yang diberikan sebagai media untuk memberikan informasi mengenai keamanan pangan berukuran A3 297x420 mm. Ukuran ini cukup besar dan dapat dilihat secara jelas oleh penyuluh dan peserta. Kegiatan penyuluhan dengan alat bantu poster terlihat pada gambar 2 .

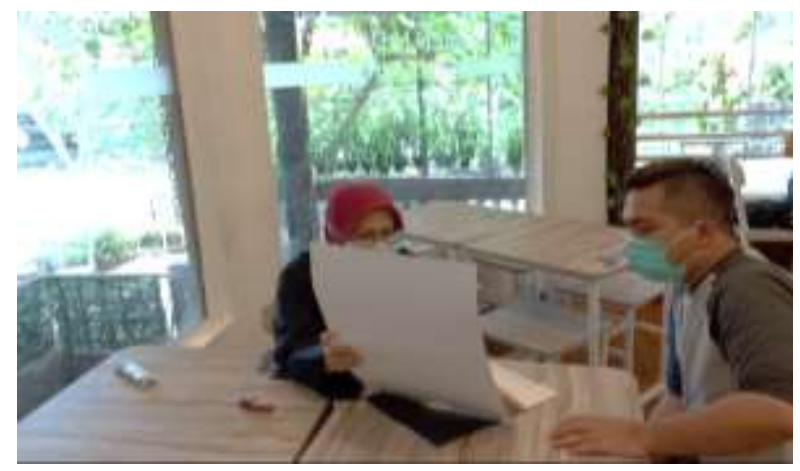

Gambar 2. Kegiatan Pemberian Materi Berupa Poster Keamanan Pangan

Memastikan keamanan pangan pada rantai makanan sebagai pengakuan bahwa tanggung jawab untuk penyediaan makanan yang aman, sehat dan bergizi dibagi di sepanjang rantai makanan oleh semua yang terlibat dengan produksi, pengolahan, perdagangan dan konsumsi makanan (Food and Agriculture Organization of the United Nations. 2017). Dengan demikian diperlukan penyuluhan pangan kepada penjamah makanan dan minuman. Mekanisme pemberian penyuluhan dimulai dari pemberian materi melaluli poster, dan pada tahap ini peserta terlihat aktif menyimak apa yang dijelaskan penyuluh.

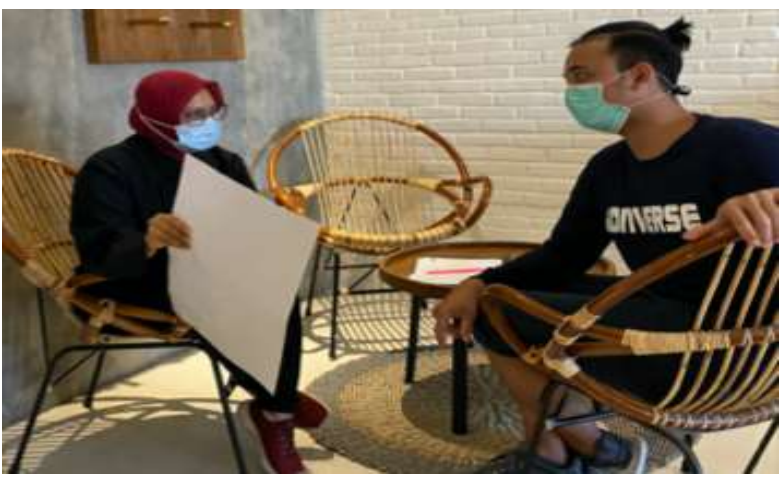

Gambar 3. Kegiatan Diskusi Mengenai Penerapan Keamanan Pangan Di Kedai Kopi

Setelah tahap pemberian materi melalui poster mekanisme selanjutnya adalah penyuluh memberi kesempatan untuk penjamah makanan dan minuman di kedai kopi untuk menceritakan penerapan keamanan pangan di tempatnya. Bisnis makanan harus mematuhi persyaratan keamanan pada makanan, mereka harus dapat menunjukkan bahwa mereka memiliki sistem pemasakan makanan hingga penyimpanan makanan dan minuman yang aman untuk memastikan bahwa makanan tetap aman untuk dimakan.
Mekanisme selanjutnya yaitu diskusi lanjut dengan merevisi penerapan keamanan pangan yang diterapkan di kedai kopi. Dibeberapa kedai kopi tentunya masih memiliki kesalahan dalam penerapan keamanan pangan sehingga penyuluh perlu memberikan beberapa tips untuk memperbaiki, terlebih dimasa pandemic covid 19 pengujung pasti lebih detail terhadap penerapan keamanan pangan di kedai café. Ditahap ini penyuluh juga menekankan bahwa penjamah makanan dan minuman juga berperan penting dalam memutus rantai penularan covid-19 hali ini sejalan dengan pendapat ahli yang meyatakan bahwa usaha jasa boga dapat menjadi tempat penularan Covid-19 karena memiliki rantai yang cukup panjang dari mulai produsen, distributor, konsumen hingga pengantaran makanan sehingga dibutuhkan penyuluhan keamanan pangan untuk memutus penyebaran berbagai macam virus dan mengambil kembali kepercayaan konsumen.

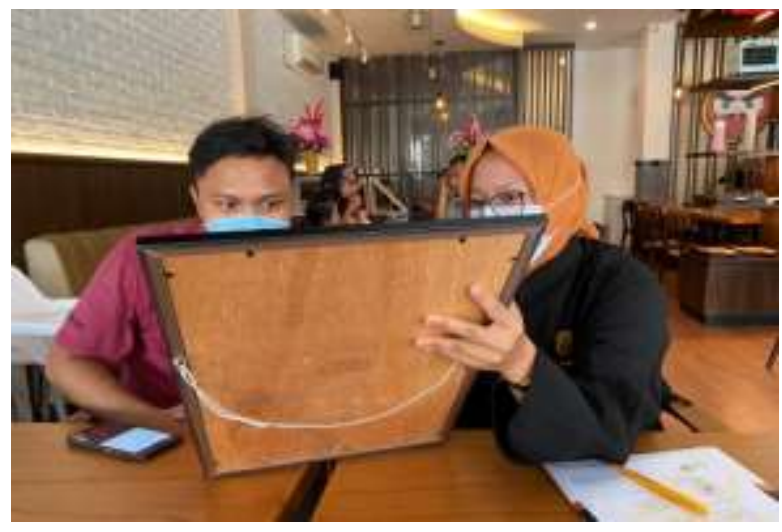

Gambar 4. Kegiatan Diskusi Lanjut dengan Merevisi Penerapan Keamanan Pangan yang Diterapkan di Kedai Kopi

Setelah diskusi selesai peserta diberi kesempatan untuk melakukan evaluasi dan terakhir mengisi absen. Keberhasilan dari kegiatan pengabdian masyarakat ini tentunya dapat diukur berdasarkan indikator peningkatan pengetahuan yang diukur menggunakan perbandingan angket pre test dan post test yang diberikan melalui google form. Hasil evaluasi pre test dan postest penyuluhan keamanan pangan dengan kode nama kedai kopi yang diberikan secara acak ditunjukkan pada Tabel 2.

Tabel 2. Hasil Evaluasi Pre Test Dan Postest Penyuluhan Keamanan Pangan Di Kedai Kopi

\begin{tabular}{lcc}
\hline Kode Kedai Kopi & Pre test & Postest \\
\hline Kedai kopi 1 & $50 \%$ & $100 \%$ \\
Kedai kopi 2 & $38 \%$ & $75 \%$ \\
Kedai kopi 3 & $38 \%$ & $88 \%$ \\
Kedai kopi 4 & $50 \%$ & $100 \%$ \\
Kedai kopi 5 & $38 \%$ & $100 \%$ \\
Kedai kopi 6 & $38 \%$ & $88 \%$ \\
Kedai kopi 7 & $38 \%$ & $88 \%$ \\
Kedai kopi 8 & $50 \%$ & $88 \%$ \\
\hline
\end{tabular}




\section{Evaluasi Pre test dan Postest Penyuluhan Keamanan Pangan}

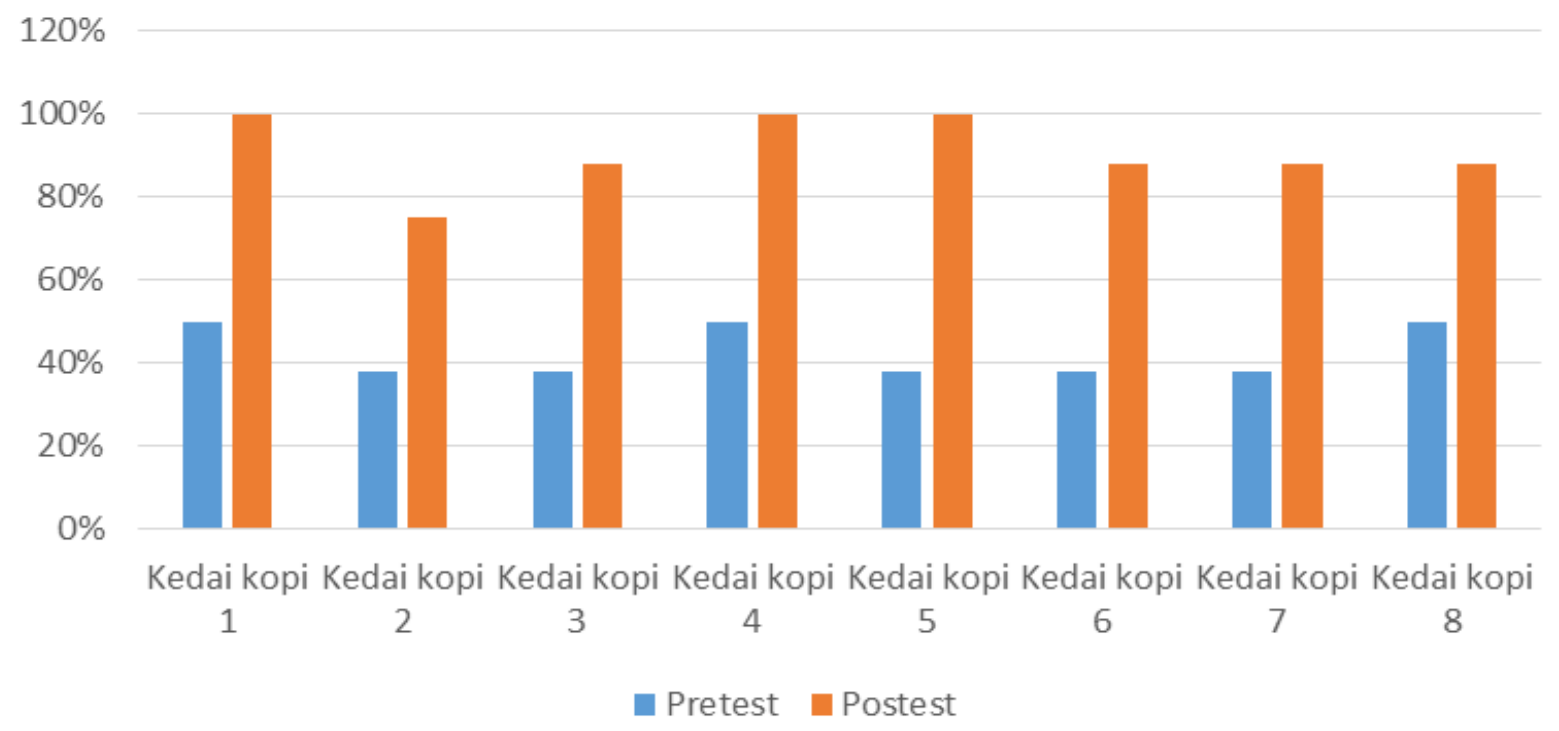

Gambar 6. Diagram Batang Evaluasi Pre test dan Postest Penyuluhan Keamanan Pangan.

Adapun apabila data pada Tabel 2 disajikan dalam bentuk diagram batang, maka hasilnya ditunjukkan sebagaimana pada Gambar 6.

Berdasarkan data pada Tabel 2 dan Gambar 6, diketahui bahwa semua pegawai di delapan kedai kopi memiliki peningkatan pengetahuan mengenai keamanan pangan. Sebagian besar pegawai merasa kegiatan pengabdian masyarakat dengan penyuluhan ini bermanfaat guna menjaga keamanan di kedai kopi sehingga dapat membuat pegawai dan pelanggan merasakan aman dan nyaman. Naiknya pengetahuan pegawai juga dapat dikarenakan oleh kemampuan penyuluh dalam menjelaskan mengenai keamanan pangan. Untuk memulai pertamatama harus menyambut pegawai dengan hangat. Membuatnya merasa nyaman dalam lingkunga penyuluhan akan membuat klien merasa lebih santai dan membuat ilmu menjadi cepat masuk. Dengan mempertahankan kontak mata dengan menunjukkan bahwa menghargai apa yang dikatakan peserta penyuluhan (Muhammad S, Kabir S.2018).

Penjamah makanan merupakan kelompok pekerjaan yang membutuhkan penyuluhan dan pelatihan yang cermat tentang keamanan pangan dan bagaimana menjalankan tugasnya dengan aman tanpa merugikan diri sendiri atau orang lain. Dengan melakukan penyuluhan akan menambah pengetahuan pegawai sehingga dapat membuat suasana tempat kerja aman dan nyaman. Sedangkan minimnya pengetahuan tentang bahan makanan dapat berisiko dan berujung pada komplikasi serius bagi penderita penyakit kronis dan alergi makanan. Penyuluh keamanan pangan ditugaskan untuk melindungi kepentingan konsumen dengan memastikan makanan yang mereka makan memenuhi standar keamanan pangan yang relevan (Hakim, Mostafa, Abdel-Rahman. 2014). Kebijakan keamanan pangan yang baik dan keputusan manajemen risiko diperlukan untuk memastikan masalah keamanan pangan perhatian tertinggi diidentifikasi, dan tindakan pengendalian yang sesuai diterapkan. Dari keberhasilan penyuluhan yang terlihat pada data yang tersaji pada gambar 3 penyuluh mengharapkan bertambahnya ilmu pengetahuan atau informasi yang didapat mengenai keamanan pangan di implementasikan secara nyata pada kedai kopi ditempat penjamah makanan tersebut bekerja.

Dengan mengadakan penyuluhan keamanan pangan dapat meminimalisir gejala penyakit bawaan makanan yang paling umum adalah: sakit perut; muntah; dan diare. Gejalanya tergantung pada penyebab penyakitnya. Gejala dapat terjadi sangat cepat setelah makan makanan, atau butuh waktu berhari-hari atau bahkan berminggu-minggu untuk muncul. Untuk sebagian besar penyakit bawaan makanan, gejala muncul 24 -72 jam setelah makanan dimakan (World Health Organization. 2009.). Dengan bertambahnya ilmu pengetahuan yang terlihat pada gambar 3 penyuluh juga mengharapkan berkurangnya kemungkinan kejadian keracunan makanan atau bahkan penularan penyakit yang diakibatkan oleh virus karena kurang hyginenya suatu kedai kopi. 


\section{SIMPULAN}

Personel industri makanan salah satunya kedai kopi tidak memiliki kesempatan untuk bekerja dari rumah dan diharuskan untuk terus bekerja di tempat kerja yang biasa. Menjaga agar semua pekerja di produksi makanan dan rantai pasokan sehat dan aman sangat penting untuk bertahan dari pandemi saat ini. Ketika bakteri, virus, atau parasit penyebab penyakit tertentu mencemari makanan, mereka dapat menyebabkan penyakit terkait makanan. Kata lain untuk bakteri, virus, atau parasit tersebut adalah "patogen". Karena penyakit yang berhubungan dengan makanan bisa serius, atau bahkan fatal, itu penting. Keamanan pangan adalah jaminan bahwa pangan tidak akan membahayakan konsumen bila disiapkan dan dimakan sesuai dengan tujuan penggunaannya. Proses penyebaran penyakit bawaan makanan dimulai dengan ciri-ciri penyakit, mencemari makanan, yang selanjutnya mengancam kesehatan individu dan masyarakat melalui makanan tersebut. Makanan sehat atau yang bisa disebut makanan aman adalah makanan yang tidak kehilangan nilai gizinya, yaitu bersih, baik secara fisik, kimiawi, maupun mikrobiologis dan tidak basi.

Mempertahankan pergerakan makanan di sepanjang rantai makanan merupakan fungsi penting yang perlu disumbangkan oleh semua pemangku kepentingan di sepanjang rantai makanan. Untuk mempermudah komunikasi penyuluhan dengan menggunakan poster, peneliti membagi pembahasan keamanan pangan menjadi 4 yaitu: 1) keamanan pangan produsen; 2) keamanan pangan distributor; 3) keamanan pangan konsumen 4) Keamanan pangan produksi makanan. Setelah di beri penyluhuan, dilakukan evaluasi dengan mengukur pengetahuan pegawai menggunakan perbandingan angket pre test dan post test yang diberikan melalui google form. Hasil dari evaluasi tersebut menyatakan bahwa semua pegawai di delapan kedai kopi memiliki peningkatan pengetahuan mengenai keamanan pangan. Sebagian besar pegawai merasa kegiatan pengabdian masyarakat dengan penyuluhan ini bermanfaat guna menjaga keamanan di kedai kopi sehingga dapat membuat pegawai dan pelanggan merasan aman dan nyaman.

\section{UCAPAN TERIMAKASIH}

Terima kasih kepada LPPM Akademi Ottimmo yang telah memberikan support dalam pelaksanaan pelatihan dan pendampingan ini. Terimakasih juga disampaikan kepada kedai kopi Soe, Kudos, kedai kopi Bugs, kedai kopi Gringo, kedai kopi Kenangan, kedai kopi Titik Terang Kopi, kedai kopi Higayon Ca N Co, kedai kopi Sini Aja yang telah memberikan kesempatan, izin, dan dukungan terhadap terlaksananya program penyuluhan ini.

\section{DAFTAR PUSTAKA}

Akkerman, R., Farahani, P., \& Grunow, M. (2010). Quality, safety and sustainability in food distribution: A review of quantitative operations management approaches and challenges. In OR Spectrum (Vol. 32, Issue 4). https://doi. org/10.1007/s00291-010-0223-2. Diakses tanggal 18 Oktober 2020.

As'ad MH, Aji JMM. 2020. Faktor Yang Mempengaruhi Preferensi Konsumen Caffe Modern Di Bondowoso. Jurnal Sosial Ekonomi Pertanian, 13(2), 182-199. Diakses dari: https://jurnal.unej.ac.id/index.php/JSEP._Diakses tanggal 5 Oktober 2020.

Bendeković, J., Naletina, D., \& Nola, I. (2015). Food Safety and Food Quality in the Supply Chain. April, 1-13. https://bib.irb.hr/datoteka/786708. TP_Bendekovic_Naletina_Nola.pdf. Diakses tanggal 5 Oktober 2020.

Food and Agriculture Organization of the United Nations. (2017). Food Safety Risk Management: Evidence-informed policies and decisions, considering multiple factors. In Food Safety and Quality Series. http://www.fao.org/documents/card/en/c/I8240EN/. diakses tanggal 20 Oktober 2020.

Food Safety Authority of Irleland. (2001). ide to Food safety Training. Level 1 - Induction Skills. Diakses tanggal 5 Oktober 2020.

Food Standarz. (2008). Food Safety StandardsTemperature control requirements Chapter 3 (Australia Only), Australia New Zealand Food Standards Code. 3, 3-4. https://www.foodstandards.gov.au/consumer/safety/faqsafety/Do cuments/Technical_Fact_Sheet_Temperature_ control_Feb_2008.pdf. Diakses tanggal 20 Oktober 2020

Infocovid Jatim. 2020. Dashboard COVID-19 Jawa Timur. Https://infocovid19.jatimprov.go.id/, Diakses tanggal 20 April 2020

Hakim, Mostafa, \& Abdel-Rahman. (2014). Assessment of the Knowledge, Attitude and Practice Towards Food Poisoning of Food Handlers in Some Egyptian Worksites. Egyptian Journal of Occupational Medicine, 38(1), 79-94. https://doi. org/10.21608/ejom.2014.789

Hariyadi, P. (2018). Keamanan Pangan: Prasyarat Dasar Pangan. Majalah Keamanan Pangan, December 2017, 10-13. Diakses tanggal 15 Oktober 2020

Knight, A. J., Worosz, M. R., \& Todd, E. C. D. (2007). Serving food safety: Consumer perceptions of food safety at restaurants. International Journal of Contemporary Hospitality Management, 19(6), 476-484. https://doi.org/10.1108/09596 110710775138. Diakses tanggal 8 Oktober 2020 
Lestari, T. R. P. (2020). Keamanan Pangan Sebagai Salah Satu Upaya Perlindungan Hak Masyarakat Sebagai Konsumen. Aspirasi: Jurnal Masalah-Masalah Sosial, 11(1), 57-72. https://doi.org/ 10.46807/aspirasi.v11i1.1523. Diakses tanggal 5 Oktober 2020

Messing, L. (2015). Keeping Foods Out of the Temperature Danger Zone. July, 1-2. Michigan: Michigan Food Safety Diakses dari: www.msue. msu.edu/safefood.

Morris Regional Public Health Partnership. (2011). Food Safety Training Manual. Devils Lake: Morris Regional Public Health Partnership. Diakses tanggal 5 Oktober 2020.

Muhammad, S., \& Kabir, S. (2018). Topics Covered Active Listening Verbal and Non-verbal Messages Attending Responding Paraphrasing Summarizing Ask Questions Probing. March 2017.

Muhyiddin, M., \& Nugroho, H. (2020). Edisi Khusus tentang Covid-19, New Normal, dan Perencanaan Pembangunan. Jurnal Perencanaan Pembangunan: The Indonesian Journal of Development Planning, 4(2). https://doi.org/ 10.36574/jpp.v4i2.120. Diakses tanggal 8 Oktober 2020

Olaimat, Shahbaz, Fatima, Munir, \& Holley. (2020). Food Safety During and After the Era of COVID-19 Pandemic. Frontiers in Microbiology, 11 (August). https://doi.org/10.3389/fmicb.2020.01854. Diakses tanggal 5 Oktober 2020
Sjafrina, N., \& Yani, A. (2013). Food Safety and the Implementation of Quality System in Food. International Journal on Advanced Science, Engineering and Information Technology, 3(4), 309. https://doi.org/10.18517/ijaseit.3.4.314. Diakses tanggal 5 Oktober 2020

Uçar, A., Yilmaz, M. V., \& Çakiroglu, F. P. (2016). Food Safety-Problems and Solutions. Significance, Prevention and Control of Food Related Diseases, 1 (April). https://doi.org/10.5772/63176. Diakses tanggal 8 Oktober 2020

WHO. (2020). COVID-19 and Food Safety: Guidance for food businesses: Interim guidance. COVID-19 and Food Safety: Guidance for Food Businesses: Interim Guidance, April, 1-6. https://doi.org/10.4060/ca8660en. Diakses tanggal 20 Oktober 2020

WHO, \& UNICEF. (2020). Air, Sanitasi, Higiene, dan Pengelolaan Limbah yang Tepat Dalam Penanganan Wabah COVID-19. World Health Organization, 1-10. https://www.who.int/docs/ default-source/searo/indonesia/covid19/whounicef---air-sanitasi-higiene-dan-pengelolaanlimbah-yang-tepat-dalam-penanganan-wabahcovid-19.pdf?sfvrsn=bf12a730_2. Diakses tanggal 20 Oktober 2020.

World Health Organization. (2009). Five Keys To Safer Food Manual Safer Food Manual. International Journal of Environmental Research and Public Health, 6, 2833-2842. http://www.mdpi.com/1660-4601/6/11/2833/. Diakses tanggal 20 Oktober 2020. 